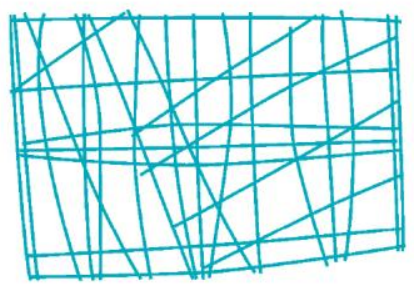

NEREUS

Núcleo de Economia Regional e Urbana

da Universidade de São Paulo

The University of São Paulo

Regional and Urban Economics Lab

ECONOMIC IMPACT OF THE EXPANSION OF FEDERAL UNIVERSITIES IN BRAZIL

Henrique E. F. Vinhais

Joaquim J. M. Guilhoto

TD Nereus 16-2012

São Paulo

2012 


\title{
Economic Impact of the Expansion of Federal Universities in Brazil
}

\author{
Henrique E. F. Vinhais and Joaquim J. M. Guilhoto
}

\begin{abstract}
There has been a strong expansion of the federal universities' system in Brazil in this century, consisted of increased public spending. This study aims to estimate the regional economic impact of this expansion, using an Interregional InputOutput model estimated for the 558 micro-regions of the Brazilian economy, at the level of 55 sectors, for the year of 2004. Treating the expansion of public spending in federal universities as a shock on the sector of Public Education, for the period 2004 to 2010, it is noticed that the federal universities' budget increased from US\$ 5.6 billion at the beginning of the century to US\$ 7.9 billion in 2010. The global results show a total effect of US\$ 6 billion in GDP (0.36\% of 2004 GDP), US\$ 10.5 billion in gross value of production, and an increase of 430,400 employed people. It appears that the smaller micro-regional economies present the highest relative impacts of the expansion of federal spending on universities, and those micro-regions, which have a capital of a federative unit, show the largest effects in absolute. Specifically, the microrregion of Diamantina - MG is the one with the largest percentage impact. Among the existing universities, the Federal University of Rio de Janeiro (UFRJ) has the largest absolute impact. But among the new ones, it stands out the Federal University of ABC (UFABC) and the Federal University of Recôncavo da Bahia (UFRB).
\end{abstract}

\section{Introduction}

Recognizing the strategic importance of education in the process of economic growth, the Brazilian government has promoted an increase in investment in education from primary school to higher education. In an attempt to minimize the educational deficit in Brazil, it has invested in expanding access to higher education, both in increasing supply of college courses and improving the regional distribution of this supply, facilitating access for students from remote locations to metropolitan areas.

During the first decade of this century, in Brazil, there was a strong expansion of the federal universities' system. It consisted of increased public spending on pre-existed university campus and construction of new campus, including the creation of new universities. This expansion is taking into account not only technical issues, but there is political influence in deciding the allocation of new campus. Besides technical issues, it has been noticed that this expansion has been influenced by political decisions about allocation of the new campus. 
In this context, the main objective of this study is to measure the economic impact of the increase in local activity due to the presence of a university. Although the conceptual idea is relatively simple, such estimation is not trivial. The usual approach is to compare basic economic indicators between the scenario with the presence of the university and the scenario without it in place (hence hypothetical).

We must first introduce the potential influences of the university in the regional economy in the short and long term. In the short term, there is what is called in the literature backward linkages, which highlighted impacts due to expenses such as expenses and direct investments of the university (deployment and maintenance establishments); teacher salaries and university employees and their direct impact on the demand for goods and services and spending by students (whether or not originating in the region). Already in the long term, as evidenced by the forward linkages, there are also effects of knowledge, referring basically to the supply side, that is, related to the expansion of human capital (higher education, qualification of manpower, creating new businesses), growth in the field of research, and attracting capital and labor more skilled workforce for the region.

As we intend to study the impact of the recent expansion of federal universities in the country, hence the model will work with the short-term impacts, as they are the only possible one to be measured in the period. Understanding the expansion of public higher education through the construction of new campus for existing or new federal universities, we can address the issue as the implementation of a public policy.

Thus, this paper will examine this expansion through the Input-Output (I-O) model, understanding this expansion as an input sector with consequent economic results, in which the expansion is treated as a shock on the sector of Public Education. It has been based on the Miller \& Blair (2009) methodology, which presents the fundamentals of the Input-Output method.

Therefore, we address the issue of the regional impact of the expansion of federal public higher education from the Input-Output model. Rolim \& Kureski (2010) studied the economic impact of short-term federal universities based on national input-output matrix of 2004 and the total costs of these universities. Here, what is proposed is to 
study the impact of the recent expansion of this universities' system, focusing on Interregional input-output matrix. Thus, we can calculate the increase in federal government spending on higher education in the period of expansion of federal universities and hence calculate its contribution to local and national development, that is, their impact on the economy.

This paper is organized as following. The next section presents the database and some descriptive analysis. The third section shows the Input-Output model. The results are analyzed on the fourth section of this paper. At the end, we present the conclusion with a summary of general results.

\section{Database}

The database used in this study is constructed based on information from 57 Brazilian federal universities, identifying the expansion and creation of new campuses in recent years, with particular attention to the new institutions. Furthermore, it identifies the cities where they are located campuses of each university.

With regard to the financial data of federal spending about the expansion of federal higher education, we will use the Integrated Financial Management System (SIAFI), opening up public expenditure actually paid to the municipality by the federal universities. This detailed information is critical to the identification of investment spending on expansion, including building and maintenance expenses. Such information is available on the website of the House of Representatives, containing the implementation of the national budget for Annual Budget Law (LOA) for each year, based on SIAFI.

Based on the above data, the shock, applied to the Education sector of the micro-region, represents the expansion of public expenditures with federal universities. Such expenditures are identified according to the university and municipality to where it is intended. While these budget expenditures have been approved in the year before their execution, we consider all expenses actually paid in a given year, regardless of the budget year. 
Specifically, with respect to the Input-Output matrix of the Brazilian productive structure, since the period of expansion of federal universities, started in 2003, is still in progress, we use the I-O matrix of 2004, representing the initial economic scenario. This matrix is characterized in 55 sectors and 558 micro-regions, representing the productive inter-regional relations. Assuming the hypothesis that the Brazilian productive structure has not changed significantly over the period up to 2010 . On this scenario, we use an annual public spending shock on each micro-region which received university expansion. So, this shock is directed to the sector of Public Education of the respective micro-region.

All monetary variables in this paper are in 2010 dollar values. As a reference, we used the annual average exchange rate of US\$ 1 to $\mathrm{R} \$ 1.759$, according to Central Bank of Brazil.

\subsection{Descriptive Analysis}

With the above described procedure, we obtain the expenses of the 57 federal universities, distributed among 27 states, including a total of 112 micro-regional shocks.

Table 1. Number of Brazilian Federal Universities by Year

\begin{tabular}{cc}
\hline Year & Universities \\
\hline 1910 & 1 \\
1920 & 3 \\
1930 & 5 \\
1940 & 6 \\
1950 & 10 \\
1960 & 20 \\
1970 & 34 \\
1980 & 37 \\
1990 & 41 \\
2000 & 42 \\
2010 & 57 \\
\hline
\end{tabular}


The evolution of the number of federal universities in Brazil is soft throughout the first half of last century, and shows, in the 1960s, a strong expansion. Between 1970 and 2000 , this evolution is again smooth, taken a strong growth in the 2000s. The years with the highest number of new federal universities were 1960 (7 universities) and 2005 (8 universities). It is important to detach that in these eight federal universities in 2005 , four ones already existed and were transformed into universities that year.

When analyzing the distribution of federal universities by state, Minas Gerais has the largest number, with 11 universities, 3 ones after 2000. Even in the recent period of expansion, Minas Gerais was the state that received most universities. However, at the region level, the Northeast was the one which received the most (six universities), with a final total of 16 federal universities.

Regarding the volume of federal government spending intended to universities, the state with the largest received volume in the years between 2000 and 2010 was the state of Rio de Janeiro (US\$ 10.40 billion), followed by Minas Gerais (US\$ 10.15 billion). However, weighting by the number of universities installed, the Federal District received an average of US\$ 3.78 billion for each university, while Rio de Janeiro and Minas Gerais received US\$ 2.60 billion and US\$ 0.92 billion, respectively. The national average was US\$ 1.15 billion.

Regarding the annual expenditures with the implementation and maintenance of federal universities, budget runs around US\$ 5.6 billion in the first half of the decade, growing steadily in the second half and reaching US\$ 7.9 billion in 2010. Altogether, between the years 2000 and 2010 there were spent almost US\$ 68 billion in federal universities.

\section{Model}

\subsection{Input-Output Matrix}

By Guilhoto \& Sesso Filho (2005), the I-O matrix is constructed from the Table of Uses of goods and services (U) and the Production Table (V). Table $\mathrm{U}$ is a product by sector matrix that shows how much each sector and each component of final demand for goods 
and services consumed (in terms of inputs, final goods and value added). Table V, in turn, is a product sector matrix that shows how much each sector produced in goods and services.

To obtain the I-O matrix (sector by sector) with industry technology-based, it is necessary to calculate the D matrix (matrix of market share), which shows, for each product, the share of industries that produces it. Thus,

$D=V(\hat{q})^{-1}$

Where $\hat{q}$ is the diagonalized vector of total production of products in the Production Table (V). Therefore, the inter-industry goods flow matrix $(\mathrm{Z})$ is the result of $U$ matrix pre-multiplied by $\mathrm{D}$. The $\mathrm{Z}$ matrix has dimension $\mathrm{n}$ by $\mathrm{n}$, where $\mathrm{n}$ is the number of sectors. The aggregate demand vector $(\mathrm{Y})$ of dimension $\mathrm{n}$ by one, is equal to $\mathrm{D}$ multiplied by the industrial production in the array of $U$ table $\left(\mathrm{Y}_{\mathrm{U}}\right)$. The total production $(\mathrm{X})$, given by a vector $\mathrm{n}$ by one, is the sum of the elements of each row of $\mathrm{Z}$ with the values of the $\mathrm{Y}$ vector. The vector $i$ is a vector of ones, $\mathrm{n}$ by 1 dimension, which allows to add the elements of each line from $\mathrm{Z}$, so that is the intermediate consumption by sector.

$Z=D \cdot U$

$Y=D \cdot Y_{U}$

$X=Z i+Y$

\subsection{The Leontief Model}

In the Leontief Model, the total output of the economy $(\mathrm{X})$ is the result of the sum of the production destined for intermediate consumption $(\mathrm{Z})$ of different sectors of the economy and final demand (Y). (Guilhoto, 2009). The inter-industry flows of goods matrix $(\mathrm{Z})$ and total output provide the information necessary to calculate the matrix of direct technical coefficients (A). The technical coefficient $\left(a_{\mathrm{ij}}\right)$ measures, in monetary 
terms, how much goods sector $\mathrm{j}$ used to its total production from sector $\mathrm{i}$. That is, it shows the proportion of inputs sold to sector $\mathrm{j}$ by sector $\mathrm{i}$ relative to the total output of sector $\mathrm{j}$.

$a_{i j}=\frac{z_{i j}}{x_{j}}$

Where $a_{\mathrm{ij}}$ is the technical coefficient represents inter-sectorial sales of sector i to sector $\mathrm{j}$ ( $\mathrm{Z}$ matrix) and $\mathrm{x}_{\mathrm{ij}}$ is the total output of sector $\mathrm{j}$ ( $\mathrm{X}$ matrix).

Therefore, the equation (5) can be represented as:

$$
X=A X+Y
$$

When there is an increase in final demand, direct effects occur not only in the production of inputs, but also trigger indirect effects. Solving equation (6), we obtain the total output required to satisfy the final demand:

$$
X=(I-A)^{-1} Y
$$

Where $(I-A)^{-1}=L$ is the direct and indirect coefficients matrix, or the inverse of the Leontief matrix. This matrix allows to obtain the direct and indirect effects on production. Each element of $\mathrm{L}\left(l_{\mathrm{ij}}\right)$ should be understood as the total output of sector $\mathrm{i}$ needed to produce one unit of final demand of sector $\mathrm{j}$ (Guilhoto, 2009).

It is noteworthy that such a model is formulated under the assumption that the relationship between $\mathrm{X}$ and $\mathrm{Y}$ is linear and homogeneous, that is, each commodity is supplied by a single activity, with constant returns to scale. There is also the hypothesis of additivity, wherein the total effect output is the sum of the separate effects.

\subsection{Calculation Methodology}

We used the Input-Output matrix of 2004, which has 55 sectors and 558 micro-regions. Based on the government spending with federal public universities by municipality, 
described previously in the database item, this spending was aggregated in microregional level. We calculated the variation between each year $(\mathrm{t})$ and the previous year (t-1), from 2004. Thus, for each of six years (2005 to 2010), we have an array of shocks, with 558 micro-regions and 57 universities.

Using the annual shock of each university in the micro-region over the Public Education sector, one can measure the direct, indirect and induced effects on micro-regions and sectors of the economy, with the definitions according to the Input-Output literature.

\section{Results}

The results of the Input-Output model, given annual shocks by university on the microregions in the Public Education sector, will be presented considering different aggregation levels: region, state, economic sector, university, and micro-region. All monetary variables are in 2010 dollar values. As a reference, we used the annual average exchange rate of US\$ 1 to R \$ 1.759, according to Central Bank of Brazil.

\subsection{Regional Impact}

Considering the combined effect of the 57 federal universities on the economy, initially we analyze the impacts on the five Brazilian regions, under a macro-analysis of the issue.

It shows that the Southeast region has the highest economic impact on gross value of production. Although it has received the greatest shocks, this region is highlighted by the greatest induced effect, which represents slightly more than $70 \%$ of the total effect. This proves the strong income effect on household consumption, given a certain increase in public spending on education. The indirect effect in absolute value is the largest in the country, but for the total effect, it is only the third largest, representing $7.8 \%$ of the total. Thus the Southeast means $47 \%$ of the total effect in Brazil, which is US\$ 10.5 billion. 
The Northeast and South region show respectively the second and third largest total effects, around US\$ 2 billion each. Although the Northeast region has highest direct effect, the South one stands out on it by the indirect and induced effects.

The Midwest region has the largest share of direct and indirect effects on your total, and consequently the lowest proportion of induced effect. Thus, compared with other regions, this region has the greatest potential to spread a shock on the adjacent sectors and micro-regions, without considering the effect on household consumption. This region that spreads over $50 \%$ of the impact on the economy through direct and indirect effects. While Southeast diffuses more than $70 \%$ by induced. Finally, the Northern region has the lowest impact on the economy.

With respect to the value added, the Southeast region has an effect of US\$2.7 billion, followed by the Northeast with US\$ 1.3 billion and South with US\$ 1.0 billion. It is worth noting the income effect on household consumption in the Southeast region of almost US\$ 1.7 billion, representing $61 \%$ of the total effect in this region. The Southeast region has $39 \%$ of the direct effect, and $45 \%$ of Brazil's total result. It is important to remember that these regional effects are the result of all effects from universities all over each region. Since the Southeast is more related to the other regions, naturally also receives the largest indirect effect coming from universities in other regions, besides the indirect effect of their own universities. Finally, the Midwest and North have an effect around $\$ 0.5$ billion. 


\section{Figure 1. Regional Effects on Value Added}

VA (Us\$ billion)

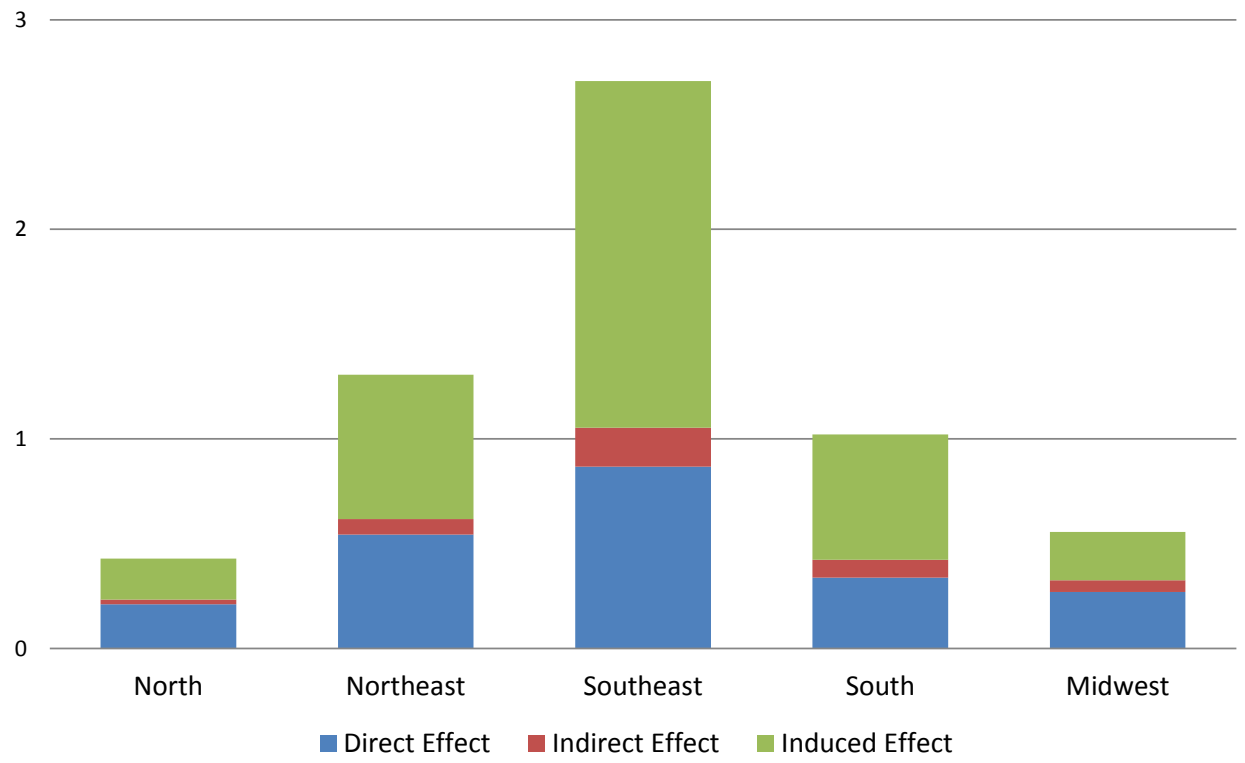

Source: Authors' calculations from the Input-Output Matrix

It is relevant to compare these results with the GDP's in regional and national levels. So, we can have a better sensitivity over the magnitude of the effects. Considering the 2004 GDP, in 2010 values as a reference (the base year of Input-Output Matrix), the impact of the expansion of government spending with federal universities is $0.36 \%$ of the national GDP, and $0.06 \%$ on average per year. The region with the greatest cumulative impact on regional GDP is the Northeast with $0.61 \%$, followed by the North and Midwest, with an impact of $0.52 \%$ and $0.37 \%$, respectively. The richest regions of the country, Southeast and South, have an impact of $0.29 \%$ and $0.35 \%$, respectively.

Considering employed people, there is an increase of 430,000 in the period, averaging 7,600 per university and 71.7 thousand per year. Regionally, the results stand out that the Southeast region, which have a monetary shock $60 \%$ higher than the Northeast one, has the greatest impact on employed people. In fact, the Northeast region shows the largest total effect in Brazil, around 142,400, against 141,700 in the Southeast one. Despite this $60 \%$ lower shock, the Northeast region has a direct effect on employed people 3.8\% higher than Southeast one. The other regions together have an increase on employed people of 146,300 . 
Anyway, given that the Southeast receives $38.3 \%$ of national shock and has the largest share in national results, with $47.1 \%$ and $45.0 \%$, respectively, on the gross value of production and value added. On employed persons, the Northeast region has $33.1 \%$ of the total effect. For gross output and value added, this region has the second highest result. The South, Midwest and North regions have an average share of $17.5 \%, 9.1 \%$ and $7.0 \%$, respectively, on the three variables.

\subsection{State Impact}

Detailing the impact regional, we analyze the impact of the expansion of public spending on federal universities at the state level. In line with the regional level, three of the four Southeast states have the greatest effect on total gross value of production. The first one is São Paulo, followed by Minas Gerais and Rio de Janeiro. For the direct effect, that is the shock itself, Minas Gerais has the largest, followed by Rio de Janeiro and São Paulo. The state of São Paulo is the largest one in total effect, US\$ 2.2 billion, due to direct and induced effects, because they are almost double of those effects in Minas Gerais, which is the state with the second largest total effect.

Outside the Southeast, the state of Rio Grande do Sul has the fourth largest total effect (US\$ 0.9 billion), and also Bahia and Pernambuco in the Northeast, with effects over US\$ 400 million.

Analyzing the increase in value added in each state, again São Paulo has the highest value, over US\$ 1.1 billion (17.5\% of the national total effect), which highlights the induced effect, which corresponds to $23 \%$ of this effect in Brazil 


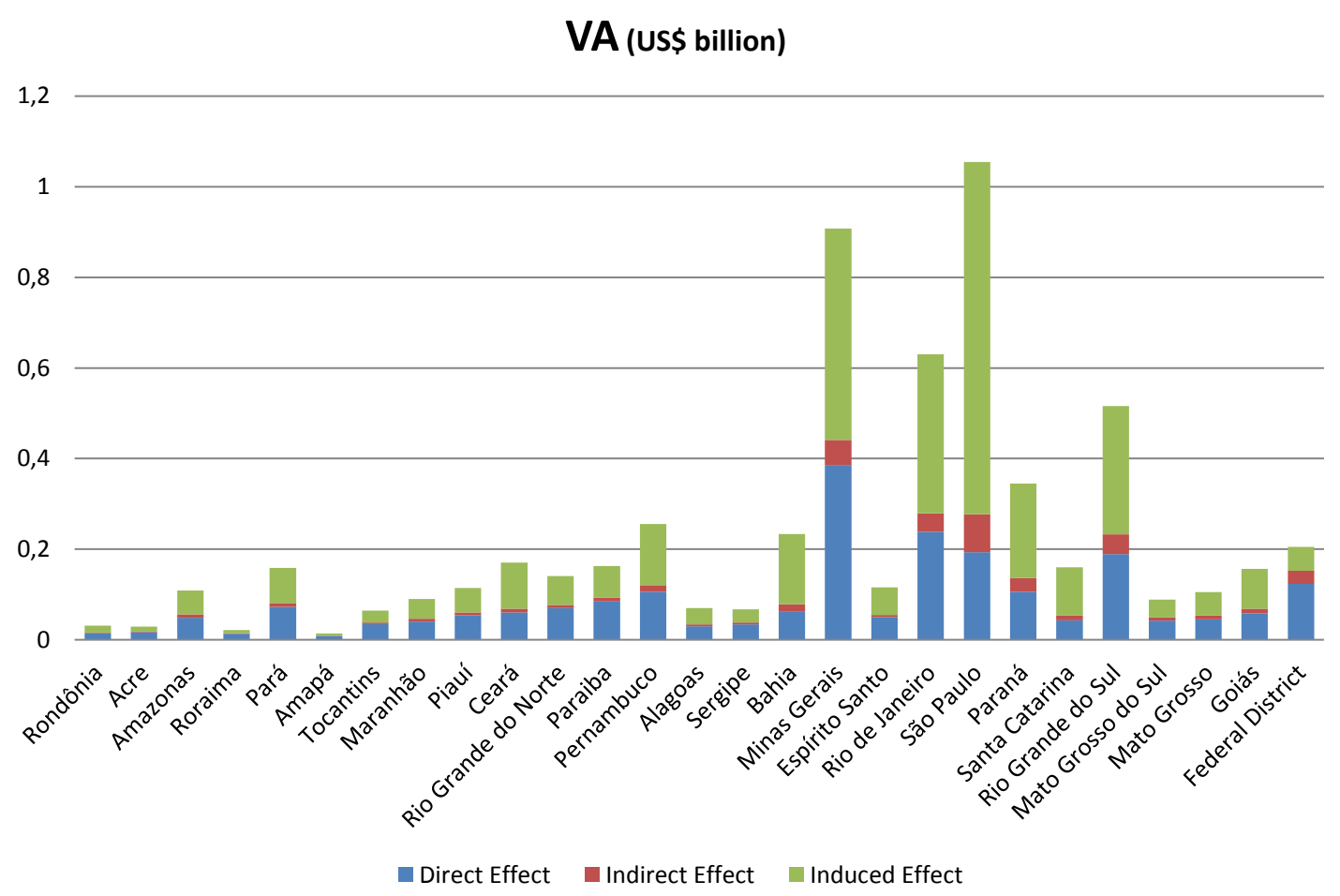

Source: Authors' calculations from the Input-Output Matrix

Although Minas Gerais and Rio de Janeiro had the largest direct effects on value added, their total effects are smaller than São Paulo. In general, the results follow the gross value of production results, including with respect to the participation of each effect on the total of each state.

Considering employed people, the results do not follow the same pattern of gross output and value added. The state with the largest total effect is Minas Gerais with an increase of 52.5 thousand (12.2\% of total Brazil). São Paulo, which is second in total effect, remains the first one in induced effect due to its economy be more developed and linked with other regions. This last fact makes this state with the largest indirect effect (increase of 33 thousand in employed people).

The state of Rio Grande do Sul, which takes the third position in effect on employed people, an increase of almost 40,000. Outside the South and Southeast regions, Pernambuco and Bahia stand out with values above 27,000. This last one has the third largest induced effect of the country, close to 20,000 . 
Overall, São Paulo has the largest effects on the national economy, except for the effect on employed people, where Minas Gerais stands. It is also worth mentioning that Rio Grande do Sul, which has effects on gross output and value added below Rio de Janeiro, has the third largest effect for employed persons, staying just below Minas Gerais and São Paulo.

\subsection{Sectorial Impact}

As described in item Calculation Methodology, the shock of each university in the micro-region is fully implemented on the Public Education sector. Thus, any direct effect, independent of the variable analyzed (gross output, value added and employed persons), is in this sector, as shown below.

Table 2. Effects of Public Education Sector

\begin{tabular}{lrrr}
\hline Effect & GVP & VA & EP \\
\hline Direct & $2,786.39$ & $2,229.78$ & 164,671 \\
Indirect & 0.19 & 0.15 & 11 \\
Induced & 0.98 & 0.77 & 55 \\
\hline Total & $2,787.56$ & $2,230.70$ & 164,737 \\
\hline \multicolumn{2}{l}{ Obs.: GVP = gross value of production (in US\$ million); } \\
VA = Value Added (in US\$ million); EP = Employed People. \\
Source: Authors' calculations from the Input-Output Matrix
\end{tabular}

It is observed that the direct effect is predominant in the Public Education sector, accounting for $99.96 \%$, independent of the variable analyzed. This shows that this sector has a low feedback effect. However, it presents significant spillover effect by causing increased demand from other sectors and micro-regions. It is important to remember that all direct effects reported in this model, at any level of aggregation, are on Public Education sector. So, there are no such effects in other sectors in a given micro-regions. 
When analyzing the effect on production from a shock of US\$ 2.79 billion on Public Education sector, it appears that the sector which has the greatest total effect is Food and Beverage, with US\$ 764 million on gross value of production. This sector has a low indirect effect (only 5\% of its total effect), but a high induced effect. This indicates that it is a sector in which household consumption is largely responsible for his performance given a demand shock in the Public Education sector.

Most of the effects on micro-regions and sectors are due to the induced effect, because the shock on Public Education sector spreads through the economy mainly via household consumption. This sector is not characterized by the provision of goods, but services and income for families through labor payment. It is always important to emphasize that the models presented here seek to measure the short-term effects. So, this shock in Public Education does not generate increased human capital, only the labor payment.

It is worth noting also the Trade sectors (US\$ 689 million) and Real State and Renting Activities ( $\$ 1$ billion). For the first sector, the effect of a university on the local market is mainly through household consumption. Its indirect effect is due to the own consumption of the university as a public company, which increases production. The second sector shows a fact mentioned in literature, media and political agents: increased demand for real estate. The implementation/maintenance of a university in a particular location increases the demand for housing by families, justifying a strong effect induced by income. Additionally, such an increase in demand leads to rising price of rents.

The Construction sector has an indirect effect of US\$ 110 million on gross value of production, which is close to $80 \%$ of its total effect. This predominance of the indirect effect is the main result of the demand for construction of the university campuses, buildings and housing. Other sectors with significant impact, close to US\$ 400 million, are Agriculture and Forestry and Electricity, Gas, and Water Supply, Transport and Post Activities, Telecommunications, Computer and Related Activities, and Financial Intermediation. With the exception of the first, which is quite correlated with other sectors of the economy, all these sectors are characterized by providing services. 
The effect of the shock of Public Education in the other sectors on the value added of other sectors, the sector that generates the highest value added is Real State and Renting Activities (almost US\$ 560 million), represented 9.2\% of the total effect on value added and $0.033 \%$ of the national GDP.

\section{Figure 3. Sectorial Effects on Value Added}

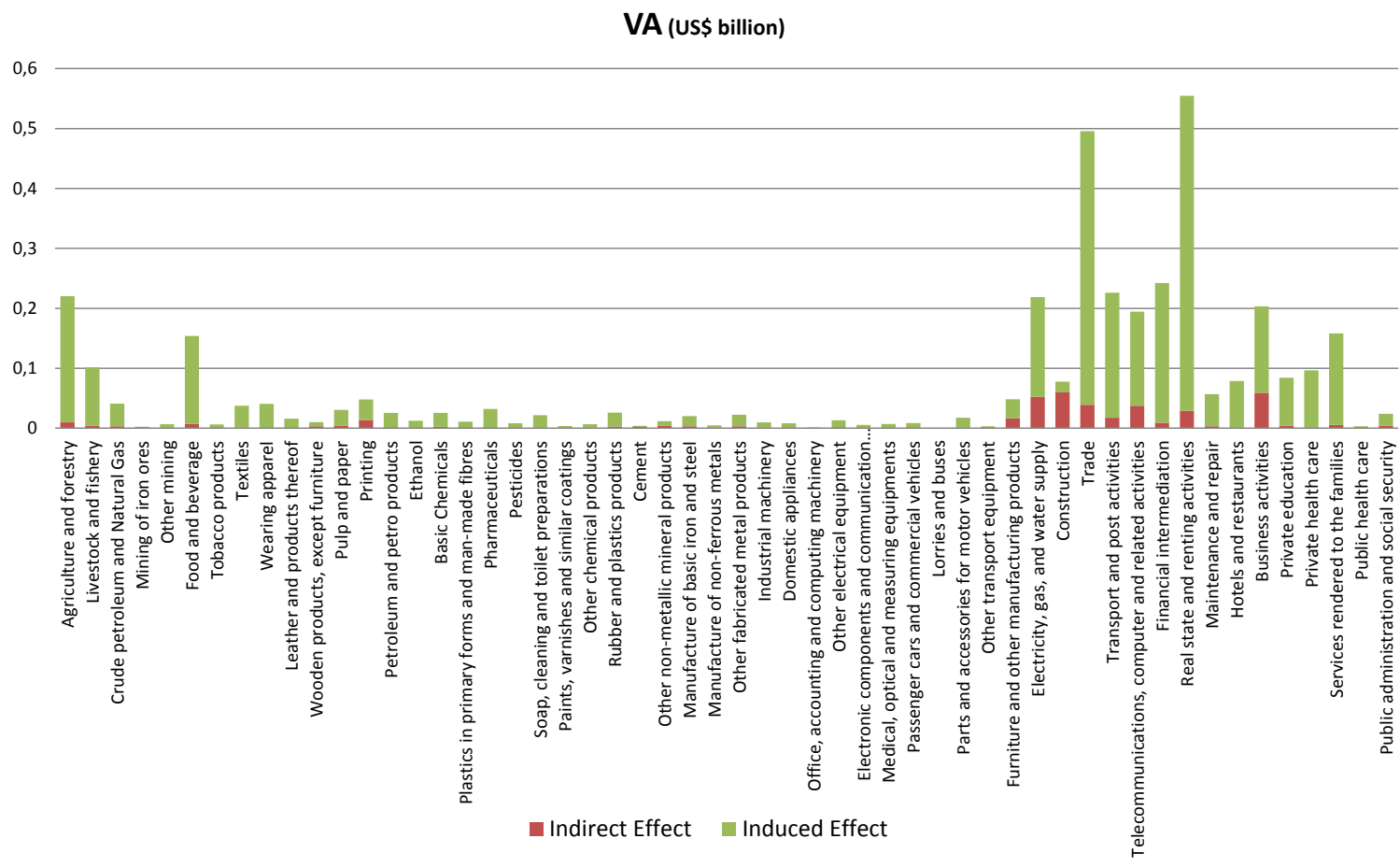

Source: Authors' calculations from the Input-Output Matrix

The Trade sector also has a strong effect on the value added (US\$ 496 million), which is $0.030 \%$ of the country's GDP and $8.2 \%$ of the total effect on value added. Again the Construction sector has the highest indirect effect, but only an effect of US\$ 78 million on the value added. The other sectors that stand out here are the same presented to the gross value of production, but the Food and Beverage sector participation has little effect on the total, corresponding to only US\$ 154 million, which is $2.6 \%$ of the total effect on value added.

Considering the effect of employed people, the sectors that stand out are Trade and Agriculture and Forestry, with effect of 48,600 and 44,500, respectively. These two sectors together account for $21.6 \%$ of the total effect on employed people. 
Two other sectors that deserve mention are Livestock and Fishery, with effect from 22,300 (5.2\%), and Services Rendered to the Families, with effect from 35,900 (8.3\% of total). Note that the Construction sector, despite its low effect $(6,400)$ of employed people, has the largest indirect effect, resulting in almost 5,000 employees.

Finally, with respect to production, the Food and Beverage sector generates the largest effect on the economy, but it has a low effect on value added and employed people. The Trade sector has major effects on all three variables, the second greatest effect on gross output and value added, and the first greatest effect on employed people, resulting in nearly 50,000 employees. The Agriculture and Forestry sector, which has a reasonable significance in monetary values, is the second largest producer of jobs to nearly 45,000 employees.

\subsection{Impact by University}

Considering annual shocks of public spending on the 57 Brazilian federal universities, we can calculate the impact of each university on the economy. Applying such shocks individually for each university, it is possible to isolate the effect of each one.

About gross value of production, the Federal University of Rio de Janeiro (UFRJ) receives the second biggest shock (Direct effect), but it has the greatest total microregional effect. This income effect is expressive probably due to the university location, because the city of Rio de Janeiro is one of the leading local economies in the country. The same phenomenon occurs with the Federal University Fluminense (UFF) in this city, which presents the fourth higher total shock and effect.

The University of Brasilia (UNB) receives the highest amount of federal public spending, but, due to the economy of the Federal District be less developed than Rio de Janeiro and São Paulo, the induced effect of this university is not so expressive. Meanwhile, the indirect effect of UNB is quite significant, being the university that causes the greatest indirect effect on the regional economy. Relatively, this indirect effect represents approximately $20 \%$ of the total effect, while, in the other universities, this effect represents less than $10 \%$ of the total. 
The Federal University of São Paulo (UNIFESP) presents the third highest total shock and effect, and presents a high induced effect, due to its location in the micro-region of São Paulo.

With relation to value added, the universities with the four largest effects are the same of the previous analysis (gross value of production). We note that the UFRJ and UNB present an effect close to US\$ 300 million, receiving shocks around \$ 150 million.

\section{Figure 4. Effects on Value Added by University}

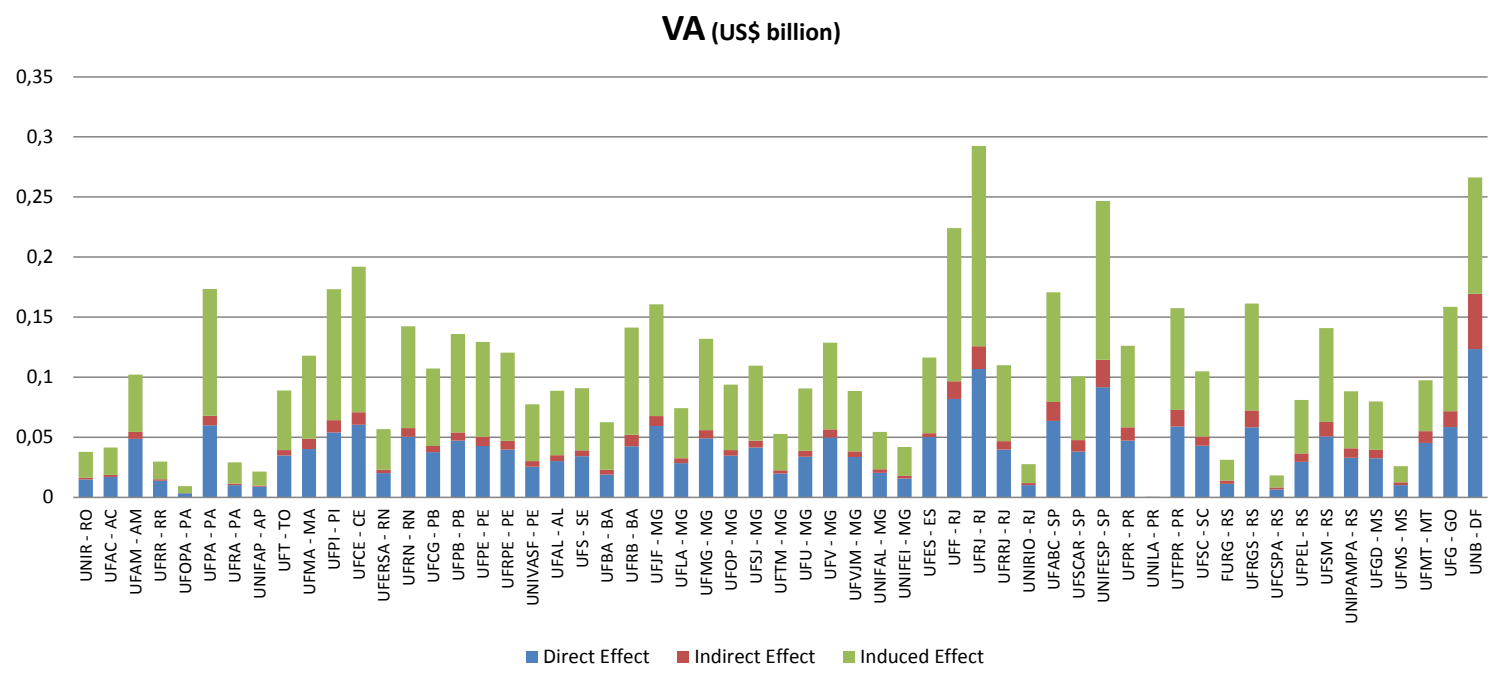

Note: The abbreviation of the university name is followed by the respective abbreviation of federative unit where the university is located (See Table A.1 at Appendix).

Source: Authors' calculations from the Input-Output Matrix

Besides the four universities mentioned, there is the Federal University of Ceará (UFCE) which presents the fifth largest total effect on the economy. However, it is located far from areas of Rio de Janeiro, Sao Paulo and Brasilia. The UFCE, despite having a direct effect similar to other universities (Federal University of Pará-UFPA, Federal University of Juiz de Fora-UFJF, Federal University of ABC-UFABC, Federal Technological University of Paraná-UTFPR, Federal University of Goiás-UFG), stands out with respect to the induced effect on the value added in the regional economy.

Although the results of the gross value of production and value added are proportionally similar, the effects on employed people show a different dynamic. The UFRJ has the greatest effect on employed people, causing an increase of almost 18,000 employed 
people. Its direct effect is over 6,000 employed people, only behind UNB, with nearly 8,000 employees. UNB has a total impact of 16,000 employed people, and the largest indirect effect with 2,000 employees. UFCE, despite not receiving one of the biggest shocks, has the second largest total effect on the employed people.

\subsubsection{Impact of New Universities}

As previously mentioned, eight new universities were created in the analyzed period, presented below:

- Federal University of Vale do São Francisco (UNIVASF) created in 2002;

- Federal University of Campina Grande (UFCG) created in 2002;

- Federal University of Grande Dorados (UFGD) created in 2005;

- Federal University of Recôncavo da Bahia (UFRB) created in 2005;

- Federal University of ABC (UFABC) created in 2005;

- Federal University of Pampa (UNIPAMPA) created in 2008;

- Federal University of Western Pará (UFOPA) created in 2009;

- Federal University of Latin American Integration (UNILA) created in 2010.

These universities together have an effect of US\$ 2.1 billion on gross value of production, US\$ 1.2 billion on added value and 53,200 employees. When compared with the effect of all federal universities in Brazil, they represent an effect about $12 \%$ of total effect on the economy.

Table 3. Effects of New Universities

\begin{tabular}{lrrr}
\hline Effect & GVP & VA & EP \\
\hline Direct & 304.79 & 237.54 & 19,508 \\
Indirect & 100.90 & 50.73 & 3,076 \\
Induced & 783.71 & 386.01 & 30,609 \\
\hline Total New Universities & $1,189.40$ & 674.27 & 53,193 \\
\hline Total All Universities & $10,453.79$ & 6.021 .54 & 430,434 \\
\hline \multicolumn{4}{c}{ Obs.: GVP = gross value of production (in US\$ million); } \\
\multicolumn{4}{c}{ VA = Value Added (in US\$ million); EP = Employed People. }
\end{tabular}

Source: Authors' calculations from the Input-Output Matrix 
Analyzing the effect of these new universities on the gross value of production, it is observed that the UFABC has the highest total effect, US\$ 300 million. It also has the largest direct effects, indirect and induced. It happens because this university received the greatest shock in public spending, and also because of its location in the state of São Paulo, which has the highest indirect and induced effects due to household income among the states.

The UFRB has the second highest impact on the economy, in the total effect, and in direct, indirect and induced effects. The third highest result is UFCG. It is striking that universities created in the early 2000s, as the UNIVASF and UFCG, present results below others created more recently, as UFABC and UFRB. The UNIPAMPA, created in 2008, stands out for having an overall effect above universities, as UNIVASF and UFGD, which were previously created. The UFOPA and UNILA have very little effect, because they are very recent.

Regarding the effect on value added, the results are similar to the ones on the gross value of production. The total impact of UFABC is US\$ 171 million, followed by UFRB with impact of US\$ 141 million. Again, the total effects follow the order of the direct effects, directly from the shock.

About employed people, the university that generates the greatest impact on the number of employed people is UFRB, with an increase of 13,400, followed by UFCG and UFABC, with almost 10,000. The UNIVASF takes the fourth position, with effect of 7,500, followed by UNIPAMPA and UFGD, affecting around 6,000 employed people.

The impact on employed people is more related to the time in which the university operates, compared with the other variables, since universities created by 2005 assume the top positions. The exception is with UFGD, created in 2005, but with less effect than UNIPAMPA, established in 2008. However, it is noteworthy that this difference is due to the direct effect of the shock. 


\subsection{Micro-regional Impact}

The micro-regional impact of the analyzed expansion considers the combined effect of all universities on each micro-region. By analyzing the impact on gross value of production, it appears that much of the effect on certain micro-region is due to the university itself, which usually accounts for at least $90 \%$ of the effect on the respective micro-region.

It is observed that from the $94.1 \%$ of the impact on micro-region Diamantina-MG, UFVJM is responsible for $93.7 \%$, that is, $0.4 \%$ is due to other universities. Among the 20 micro-regions considered, Petrolina - PE presents the biggest difference with the other universities accounting for $0.8 \%$ of the increase on gross value of production. It is important to remember that these differences are due to indirect and induced effects, because the direct effects are related to the own university located in the micro-region. Juiz de Fora - MG has the largest absolute change in the subgroup considered, an increase of US\$133 million, followed by Santa Maria - RS, with US\$ 100 million on gross value of micro-regional production.

With regard to the value added, the results are not very different. The micro-region Diamantina - MG has effect of UFVJM of $13.4 \%$ on micro-regional GDP, and the effect of other universities of only $0.1 \%$. 
Figure 5. Highest Micro-regional Effects on Value Added

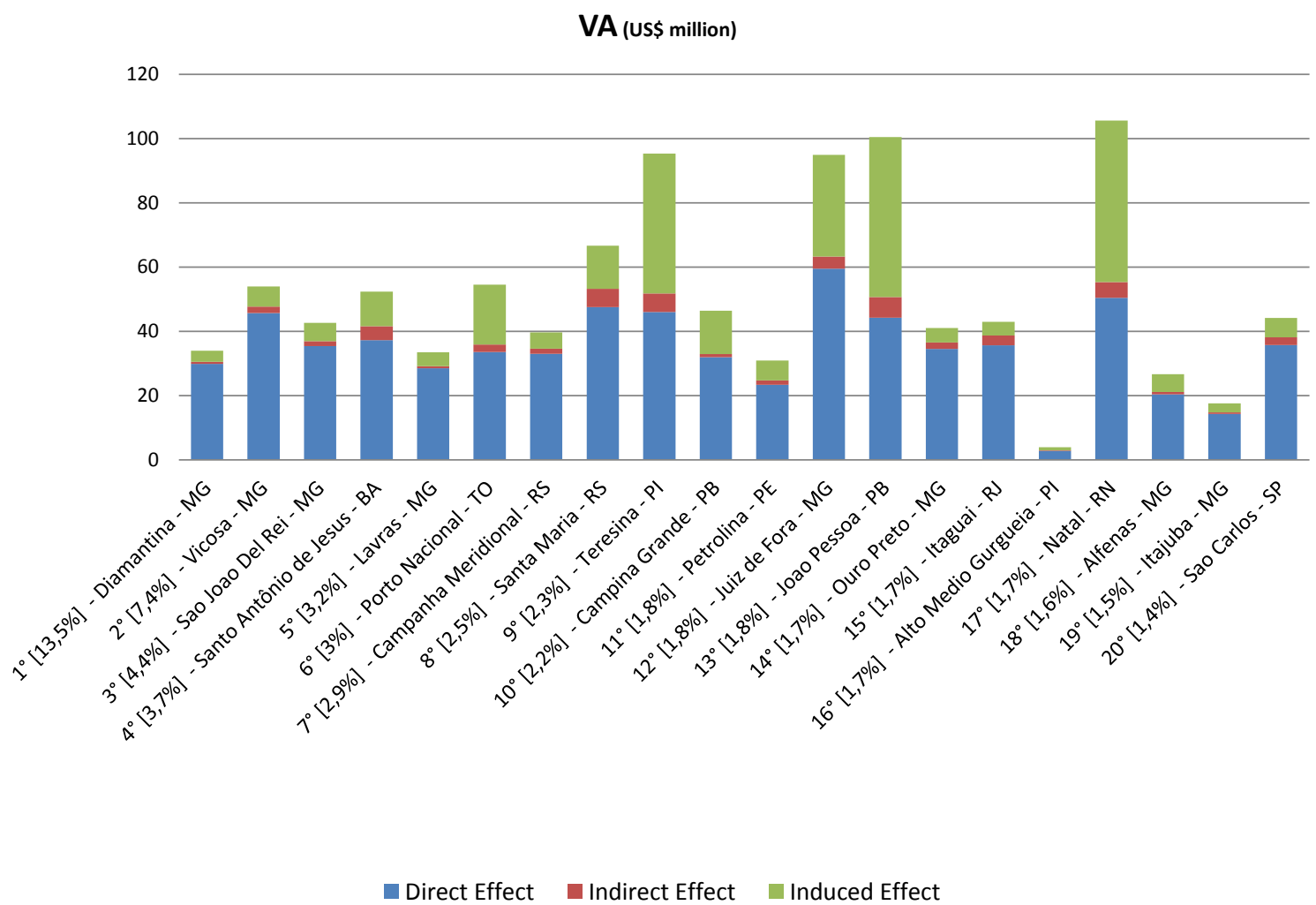

Source: Authors' calculations from the Input-Output Matrix

Among the 20 micro-regions with higher percentages effects, the micro-region João Pessoa has the greatest impact from other universities, reaching $0.5 \%$. The Federal University of Paraíba (UFPB) has an impact of $1.3 \%$ on micro-regional GDP. In this subgroup analysis, Natal - RN has the largest absolute impact on GDP, with increase of value added of US\$ 106 million, followed by João Pessoa - PB, with US\$ 100 million.

Considering the effect on employed people, the 20 micro-regions with the highest percentage impact on the stock of employed people are the same ones considered in value added analysis, regardless of the effect is due only to local university or considering other universities.

Again the micro-region Diamantina - MG is the one that has the greatest impact, with UFVJM taking effect of $95 \%$ on the stock of employed people, and other universities impacted by only $0.4 \%$. Within the subgroup of 20 micro-regions with the highest percentage effects, Petrolina - PE is the one with the greatest impact from other universities, reaching almost $0.7 \%$, and UNIVASF being responsible for an effect close 
to $5.9 \%$ on the number of employed people. With respect to absolute values, in this subgroup, Santo Antônio de Jesus - BA has the greatest impact, with an increase of 6,100 employees, followed by Santa Maria - RS, with 5,800 on the stock of employed people.

Analyzing the absolute total effects on value added, São Paulo has the largest impact (US\$ 829 million) on GDP, but this effect represents only $0.4 \%$ of GDP in this microregion, being the 82nd position among the largest relative impacts on micro-regional GDP. The major economies of Brazil occupy the top positions, except that Brasilia has the third largest GDP and is in 6th position. The 10 micro-regions with the greatest absolute effects account for $52.4 \%, 51.5 \%$ and $43.0 \%$ of the total impact on gross production, value added and employed people respectively in Brazil.

Finally, considering the impact of each individual university on their respective microregion, the largest absolute effects are in Rio de Janeiro - RJ with UFRJ and Brasilia DF with UNB, however with low effect on the stock. It appears that the smaller microregional economies receive the major impacts of the expansion of government spending with federal universities, and those that have capital units of the federation present the largest effects in absolute values.

\section{Conclusion}

Given the issue of the regional impact of the expansion of federal public higher education, we used the Input-Output model, in order to study the short-term economic impact of federal universities on economic variables Gross Value of Production, Value Added and Employed People. We sought to use the increased federal government spending on higher education between 2004 and 2010, and the Matrix Input-Output of 2004, applying annual micro-regional demand shocks on the Public Education sector.

Besides the Input-Output matrix, we used the database SIAFI, which allowed calculating annual public spending of universities by municipality, adding up later in micro-regions. The strong expansion of public spending occurred clearly from 2005 , justifying the use of Input-Output Matrix of 2004 as the basis for the model. 
Given a total shock of US\$2.79 billion in the period, the measured impact on Brazil was US\$ 10.5 billion of gross value of production, US\$ 6 billion on GDP, which represents an effect of $0.36 \%$ of the GDP in 2004, and an increase of 430,400 employed people.

Rolim \& Kureski (2010) estimate, based on the Higher Education Census 2005, the federal universities generate about 1.22 million jobs in Brazil. The correspondence between this result and the estimated one here on this paper is not straightforward, since an employed person can work in more than one job. However, considering the most conservative case, with matching of one job for each employed person, one can conclude that the expansion of federal universities have an impact of at least $35 \%$ of the total employment generated by universities in the economy.

When analyzing the regional level, it is observed that the Southeast receives $38.3 \%$ of national shock and has the greatest share in the outcome of the country, with $47.1 \%$ and $45.0 \%$, respectively, on the gross value of production and value added. On employed persons, the Northeast region receives $33.1 \%$ of the total effect.

In the state level, São Paulo has the largest effects on the Brazilian economy, except for the effect on employed people where Minas Gerais stands. It is also worth mentioning that Rio Grande do Sul, which has effects on gross output and value added below Rio de Janeiro, has the third largest effect for employed people, staying just below Minas Gerais and São Paulo. When analyzing the regions of states, it appears that the smaller micro-regional economies present the highest relative impacts of the expansion of federal spending on universities, and those micro-regions, which have a capital of a federative unit, show the largest effects in absolute.

Observing the impact of each university on their respective micro-region is evident that the 10 largest absolute impacts from their federal universities are responsible for approximately $20 \%$ of total impacts in Brazil with respect to gross value of production, value added and employed people. Considering all the universities together, the total accumulated effects on micro-regions are expressive. 
About sectors, considering the impact on production, we realize that the Food and Beverage sector generates the largest effect on the economy. However, its impact has little representation on value added and employed people. The Trade sector has major effects on all three variables, the second greatest effect on gross value of production and value added, and the first greatest effect on employed people. The Agriculture and Forestry sector, which has a reasonable significance in monetary values, is the second largest producer of jobs, presenting an economic impact of almost 45,000 employed people.

Finally, among the universities, UFRJ in Rio de Janeiro and UNB in Brasília present the largest effects on the economy. However, considering only the new universities, UFABC has the largest effects on gross value of production and value added. On employed people, it comes in third, below the UFRB and UFCG.

\section{References}

ANDIFES - National Association of Directors of Federal Institutions of Higher Education (Associação Nacional dos Dirigentes das Instituições Federais de Ensino Superior). $h t t p: / / w w w$. andifes.org.br.

Brazilian Federal Government. WebSite of the Brazilian House of Representative. Available at: http://www2.camara.gov.br/atividade-legislativa/orcamentobrasil/ orcamentouniao/loa/execucao.html.

Carvalho, C. (2011) A Política Pública para a Educação Superior no Brasil (19952008): Ruptura e/ou Continuidade? PhD Thesis presented to the Department of Economics of the State University of Campinas. $441 \mathrm{p}$.

Garrido-Yserte, R.; Gallo-Rivera, M. (2010) The Impact of the University upon Local Economy: Three Methods to Estimate Demand-Side Effects. The Annals of Regional Science, vol. 44(1), pages 39-67, February.

Gonçalves, E. (2006) Estrutura Urbana e Atividade Tecnológica em Minas Gerais. Economia Aplicada, 10(4): 481-502.

Guilhoto, J. (2009) Análise de Insumo-Produto: teoria, fundamentos e aplicações. Working book. Department of Economics, University of São Paulo, 2009.

Guilhoto, J; Sesso Filho, U. (2005) Estimação da matriz insumo-produto a partir de dados preliminares das contas nacionais. Economia Aplicada, 9 (2), pp. 277-299. 
Liu, H.; Polenske, K.; Guilhoto, J. (2010) China and Brazil Productive Structure and Economic Growth Compared: 1980's to 2000's. Paper presented at 57th Annual North American Meetings of the Regional Science Association International. Denver, USA, November.

MEC - Ministry of Education. (2009) Reuni 2008 - Relatório de Primeiro Ano. Development Board of the Federal Higher Education Institutions. Brasília-DF. 17p. MEC - Ministry of Education. (2008) O Plano de Desenvolvimento da Educação: Razões, Princípios e Programas. Brasília-DF.43p.

MEC - Ministry of Education. (2007) Diretrizes Gerais: Documento Complementar. Development Board of the Federal Higher Education Institutions. Brasilia-DF. 14p.

Miller, R.; Blair, P. (2009) Input-Output Analysis: Foundations and Extensions. Second Edition. Cambridge: Cambridge University Press.

Parsons, R.; Griffiths, A. (2003) A Micro Economic Model to Assess the Economic Impact of Universities: A Case Example. Association for Institutional Research. Professional File. No. 87, 24p.

Report of the Working Group on Financing for Education (Relatório do Grupo de Trabalho sobre Financiamento da Educação) (2001) RBEP - Brazilian Journal of Pedagogical Studies (Revista Brasileira de Estudos Pedagógicos). Brasília-DF. 19p.

Rolim, C.; Kureski, R. (2010) Impacto Econômico de Curto Prazo das Universidades Federais na Economia Brasileira. Paper presented at the XIII Regional Economic Meeting (South ANPEC). Porto Alegre-RS, August 11-13.

Siegfried, J., Sanderson, A.; Mchenry, P. (2007) The Economic Impact of Colleges and Universities. Economics of Education Review, vol. 26(5), pp. 546-558.

Výrostova, E.; Výrost, T. (2007) Measuring the Role of Universities in Regional Development. Technical University of Košice, Faculty of Economics - 2nd Central European Conference in Regional Science - CERS, 2007.pp. 1141 - 1149. 


\section{Appendix}

Table A.1. Universities and Abbreviations

\begin{tabular}{|c|c|c|c|}
\hline \multicolumn{2}{|l|}{ University } & \multicolumn{2}{|l|}{ State } \\
\hline Abbreviation & University & Abbreviation & State \\
\hline FURG & Federal University Foundation of Rio Grande & $\mathrm{RS}$ & Rio Grande do Sul \\
\hline UFABC & Federal University of $\mathrm{ABC}$ & $\mathrm{SP}$ & São Paulo \\
\hline UFAC & Federal University of Acre & $\mathrm{AC}$ & Acre \\
\hline UFAL & Federal University of Alagoas & $\mathrm{AL}$ & Alagoas \\
\hline UFAM & Federal University of Amazonas & $\mathrm{AM}$ & Amazonas \\
\hline UFBA & Federal University of Bahia & BA & Bahia \\
\hline UFCE & Federal University of Ceará & $\mathrm{CE}$ & Ceará \\
\hline UFCG & Federal University of Campina Grande & $\mathrm{PB}$ & Paraiba \\
\hline UFCSPA & Federal University of Health Sciences of Porto Alegre & $\mathrm{RS}$ & Rio Grande do Sul \\
\hline UFERSA & Federal Rural University of Semi-Arid & RN & Rio Grande do Norte \\
\hline UFES & Federal University of Espírito Santo & ES & Espírito Santo \\
\hline UFF & Federal University Fluminense & RJ & Rio de Janeiro \\
\hline UFG & Federal University of Goiás & GO & Goiás \\
\hline UFGD & Federal University of Grande dourados & MS & Mato Grosso do Sul \\
\hline UFJF & Federal University of Juiz de Fora & MG & Minas Gerais \\
\hline UFLA & Federal University of Lavras & MG & Minas Gerais \\
\hline UFMA & Federal University of Maranhão & MA & Maranhão \\
\hline UFMG & Federal University of Minas Gerais & MG & Minas Gerais \\
\hline UFMS & Federal University of Mato Grosso do Sul & MS & Mato Grosso do Sul \\
\hline UFMT & Federal University of Mato Grosso & MT & Mato Grosso \\
\hline UFOP & Federal University of Ouro Preto & MG & Minas Gerais \\
\hline UFOPA & Federal University of Western Pará & PA & Pará \\
\hline UFPA & Federal University of Pará & PA & Pará \\
\hline UFPB & Federal University of Paraíba & $\mathrm{PB}$ & Paraiba \\
\hline UFPE & Federal University of Pernambuco & $\mathrm{PE}$ & Pernambuco \\
\hline UFPEL & Federal University of Pelotas & $\mathrm{RS}$ & Rio Grande do Sul \\
\hline UFPI & Federal University of Piauí & PI & Piauí \\
\hline UFPR & Federal University of Paraná & PR & Paraná \\
\hline UFRA & Federal Rural University of Amazônia & PA & Pará \\
\hline UFRB & Federal University of Recôncavo da Bahia & BA & Bahia \\
\hline UFRGS & Federal University of Rio Grande do Sul & $\mathrm{RS}$ & Rio Grande do Sul \\
\hline UFRJ & Federal University of Rio de Janeiro & RJ & Rio de Janeiro \\
\hline UFRN & Federal University of Rio Grande do Norte & $\mathrm{RN}$ & Rio Grande do Norte \\
\hline UFRPE & Federal Rural University of Pernambuco & PE & Pernambuco \\
\hline
\end{tabular}




\begin{tabular}{llll} 
UFRR & Federal University of Roraima & RR & Roraima \\
UFRRJ & Federal Rural University of Rio de Janeiro & RJ & Rio de Janeiro \\
UFS & Federal University of Sergipe & SE & Sergipe \\
UFSC & Federal University of Santa Catarina & SC & Santa Catarina \\
UFSCAR & Federal University of São Carlos & SP & São Paulo \\
UFSJ & Federal University of São João del Rei & MG & Minas Gerais \\
UFSM & Federal University of Santa Maria & RS & Rio Grande do Sul \\
UFT & Federal University of Tocantins & TO & Tocantins \\
UFTM & Federal University of Triângulo Mineiro & MG & Minas Gerais \\
UFU & Federal University of Uberlândia & MG & Minas Gerais \\
UFV & Federal University of Viçosa & MG & Minas Gerais \\
UFVJM & Federal University of Vales do Jequitinhonha e Mucuri & MG & Minas Gerais \\
UNB & University of Brasília & DF & Federal District \\
UNIFAL & Federal University of Alfenas & MG & Minas Gerais \\
UNIFAP & Federal University of Amapá & AP & Amapá \\
UNIFEI & Federal University of Itajubá & MG & Minas Gerais \\
UNIFESP & Federal University of São Paulo & SP & São Paulo \\
UNILA & Federal University of Latin American Integration & PR & Paraná \\
UNIPAMPA & Federal University of Pampa & RS & Rio Grande do Sul \\
UNIR & Federal University of Rondônia & RO & Rondônia \\
UNIRIO & Federal University of the State of Rio de Janeiro & RJ & Rio de Janeiro \\
UNIVASF & Federal University of Vale do São Francisco & PE & Pernambuco \\
UTFPR & Federal Technological University of Paraná & PR & Paraná \\
\hline
\end{tabular}

